See discussions, stats, and author profiles for this publication at: https://www.researchgate.net/publication/278033569

\title{
Policy for Development and Use of Open Educational Resources in Covenant University
}

Article · December 2014

DOI: 10.1109/ICWOAL.2014.7009198

CITATIONS

7

5 authors, including:

Conrad Asotie Omonhinmin

Covenant University, Ota, Ogun State, Nigeria.

61 PUBLICATIONS 379 CITATIONS

SEE PROFILE

Prof. Aderemi A. Atayero

Covenant University Ota Ogun State, Nigeria

260 PUBLICATIONS 1,661 CITATIONS

SEE PROFILE

Some of the authors of this publication are also working on these related projects:

Developing an Entrepreneurial Ecosystem View project

Project

Medicinal Plant Diversity and Management View project
Omolola Omotosho

Covenant University Ota Ogun State, Nigeria 33 PUBLICATIONS 137 CITATIONS

SEE PROFILE 


\title{
Policy for Development and Use of Open Educational Resources in Covenant University An Open Access Policy in Covenant University.
}

\author{
Conrad A. Omonhinmin, Omolola E. Omotosho, Adebayo Akomolafe, Aderemi A. Atayero \\ Covenant University - CU, 112233, Ota \\ Nigeria. \\ conrad.omonhinmin@covenantuniversity.edu.ng
}

\begin{abstract}
Establishing an Open Access Policy (OAP) in an academic institution is unlike establishing other policies the institution might have developed. An OAP in an academic institution would require the active participation of all stakeholders; researcher/faculty, library, management (Administration) and even students. OAP development in Covenant University spanned a total of 13 months; covering, draft policy development, legal review of policy, review of OAP by the university community, revision of policy document following institutional review, adoption of OAP by university community, ratification of OAP by University Senate. The OAP development period also saw a deliberate effort by the university through its Open Access (OA) office to sensitize its community on the drive for $\mathrm{OA}$, as well as educates strategic units and departments of the university on $\mathrm{OA}$ issues to bring such key units and department abreast on $O A$ and ensure proper execution on the OAP. Covenant University now operates an OAP for the development and use of open educational resources, alongside Institutional Repository (IR) guidelines. The OAP covers publications and access to research information, pedagogy materials and tools as well as access to non-research or pedagogical materials in the university and by the university workers, researchers and faculty.
\end{abstract}

Index Terms - Open Access Policy, University, Community, PBL, ODL, Institutional Repository.

\section{Introduction}

Establishing an Open Access Policy (OAP) in an academic institution is unlike establishing any other kind of policy, mainly because it is often a policy that requires the full engagement of all stakeholders in that institution. The concern is centered on issues of personal rights and institutional rights are that are involved in OAPs. While other policies may be management-driven, OAPs are essentially contributors-centered as the policy applies to contributors (faculty) more than the administration. One of the focal points of the OAP stated in its objectives is to;

“...allow unrestricted access to all publications to read, search, download, copy, distribute, print, or link to the full texts of these articles, ... use them for any other lawful purpose through free availability on the public internet."
It is the access to the outputs of the research works of these contributors that is the centerpiece of the policy and because the policy seeks to drive the increase visibility of the works of its faculty/researchers to the society and by so doing the visibility of the institution [1].

\section{ACADEMIC FREEDOM AND OPEN ACCESS PUBLISHING}

Faculty are most concern about their academic freedom and often are reluctant to commit to any policy that tends to undermine their academic freedom. Hence, establishing an OAP in a university requires a good level of education on a number of issues such as; types of Open Access (OA), whether green $\mathrm{OA}$ or gold $\mathrm{OA}$; academic freedom, compliance with the dictates of the policy, deposition of materials in institutional repository, self archiving, waivers [2]. Hence part of its objectives further reads;

"...ensure authors and contributors have the appropriate copyright to allow these activities, and to ensure that such copyright permits authors/contributors only control over the integrity of their work and the right to be properly acknowledged and cited."

In another instance;

“...serve the faculty's interests by allowing articles to receive open distribution, simplifying author's retention of distribution rights, aiding preservation, and providing unified action to discourage publishers from rejecting articles because they shall be available in open access. In circumstances, where the license appears injurious to the interest of a faculty member, the policy shall allow for a waiver of the license or delay of distribution."

Ultimately, the focal point of the policy is to ensure contributors/faculty retain the power of "choice" as to where they publish their works, offers options on how to go about doing so to facilitate Open Access to their works as well as improves their right and control over their works than is usually provided under standard publishing agreements. The 
twin "phobias" of institutional ownership of their works and subjection to a new form of coercion has to be allayed by educating them on the non-exclusion rights provisions and the waiver options [3].

\section{OPEN ACCESS IN COVENANT UNIVERSITY - OACU}

To situate properly the issues of Open Access in Covenant University, the university management constituted the Open Access in Covenant University, co-ordinated by a director in the office of the Deputy Vice Chancellor for Academics. The unit oversees, plan and execute sundry activities for effective advocacy on OA, propose and recommend appropriate policies, approaches and programs to ensure the university community is fully aware and actively participate in OA programs as well as realign and even project OA-centered activities.

\section{UNIVERSITY-WIDE OAP}

A university-wide OAP was initiated at Covenant University as with other great research institutions like MIT. Unlike in some instructions with schools or colleges-based OAPs, a university-wide OAP, reduces the instances of divergence of standards and applications of the policy, ensures a common platform for the administration of the policy across all spheres of the university, and discourages duplication of efforts or postures of "segregation" within the university $[4,5]$. CU is the first university, public or private, in Nigeria to adopt a university-wide open access policy. Though a number of initial OAPs where voluntary and popular, recent evidences show that mandatory OAPs are better programmed to produce the level of self-archiving that institutions seeks. The introductory part of the overview on the OAP in CU reads:

\section{Covenant University requires her faculty... to be involved in researches that are solution-based and public-oriented and whether publicly, privately or corporately funded ensure that such works, whether scientific research results,...be made accessible to all for the good and benefit of all.}

Hence, CU in its OAP "requires" rather than "encourages" because only such focus will provide the institution with the increased visibility and other impacts that OA promises [6].

\section{CHANGE FROM EXISTING PLATFORM}

One major obstacle faced by a new initiative such as OA in a particularly traditional circle like publishing by scholars is not so much of the demerits inherent in the initiative, but more of the inertia to pursue the new pathway or an innate distrust (whether genuine or unfounded) for such new initiative(s) [3]. To alley such phobia, the OAP clearly states that the institution provides necessary impetus for motivating faculty in the anticipated direction as;
"CU is committed to providing necessary financial, organizational, and non-material supports that shall allow the concept of Open Access work under optimum conditions."

The scope of such supports span ICT, infrastructures, capacity building, as well as financial support for faculty publishing in OA journals.

The task of establishing a university-wide OAP is better appreciated when one considers the divergence of views on the subject of publishing research outcomes, the peculiarities of publishing in various fields of studies and the already existing paradigms regarding publishing of scholarly works contributors/faculty are accustomed to. A great deal of efforts and time are devoted to educating faculty from various fields on the benefits OA and the need to embrace it, without losing out on the "prestige" existing publishing platforms may offer.

\section{TIME LINE FOR OAP IN COVENANT UNIVERSITY}

Covenant University OAP move spanned a total of 13 months;

- Draft policy development,

- Legal review of policy,

- Review of OAP by the university community,

- Revision of policy document following institutional review,

- Adoption of OAP by university community,

- Ratification of OAP by university senate.

\section{CAPACITY BUILDING - ORIENTATION \& TRAINING}

Sensitize its community on $O A$.

To attain the fully sensitization of its faculty on OA and thus the OAP initiative, several weekly meetings were organized particularly with the weekly Faculty Fellowship (FFF) of the university, culminating in the university's first Open Access Day in July, 2013.

Educate strategic units and departments of the university on $O A$

To ensure a proper appreciation $\mathrm{OA}$ and the administration the OAP in the university, the Open Access in Covenant University (OACU) office organized trainings for the strategic units of the university on the peculiar functions and duties expected of them. Such centers/units/departments include the:

Centre for Systems and Information Services (CSIS) - the centre handles all ICT issues in the university, working with the ICT committee of the university.

Centre for Learning Resources (CLR) - the university's library, it manages all libraries and library issues in the university as well as the repository alongside the CSIS.

Corporate and Public Affairs (CPA) - the directorate constitute the image manager of the university and handles the corporate and public affairs publications of the university. 
Legal Unit, Covenant University (LUCU) - The unit handles all legal matters of the university and are thus important to the drafting and interpretations of the legal aspect of the policy as well as the various licensing that may be adopted in the administration of the OAP.

\section{OUTCOMES}

Revamped Journals - With the OAP, the university revamped its moribund journals and re-launched them as green OA journals under the Covenant Journals. The Covenant Journals manages seven (7) journals covering physical and life sciences, communication, business and social sciences, political and international affairs, informatics and communication technology, languages, and built environment.

Launched Fund for OA Scholarly Publishing - In 2013, the university launched a publication fund to assist faculty in publishing in fee-based OA journals.

ICT Policy - Following the OA awareness, there was the need for a robust ICT policy that allows for the productive implementation of the OAP, leading to a revision of the institution's ICT policy.

Institutional Repository Guidelines (IRG) - As part of the OAP, an Institutional Repository Guidelines (IRG) document was generated to ensure faculty are aware of the procedures and rules guiding the archiving of their works on the institutional repository. The IRG reads;

"Covenant University has set up an Institutional Repository (IR) called CUSpace to make available the scholarly articles provided by its faculty members. This repository is supported the by the institution of Covenant University to ensure its availability, longevity, and functionality, to the extent technologically feasible. The repository shall be backed up, mirrored, and made open to harvesting..."

The institution currently runs a DSpace and an eprints repositories

http://covenantuniversity.edu.ng/Library/InstitutionalRepository.

Improved Archiving in Repository - Back by the IRG, archiving on the university's institutional repository increased greatly. Institutional repositories now constitute a key part of scholarly communication, providing alongside OA literature services like usage reporting for authors and institution, article list download, organized search, peer review system and publishing of institutional works [7].

\section{DEVELOPMENT AND USE OF OPEN EDUCATIONAL RESOURCES}

The development of an OAP in the university also took cognizance of the area of Open Educational Resources (OER) for improved teaching and learning as well as for development and dissemination of Pedagogy materials and tools. This brought about the deployment of open courseware and learning tools in the University.

\section{STUDENT AND OPEN ACCESS SPREAD}

$\mathrm{OA}$ promises to unlock access to the latest research information in any discipline to students. It also promises to help them attain a complete education; expand their knowledge horizon beyond what is available to the most recent and relevant information in their field of study [8]. This assertion also applies to faculty tasked with providing up-todate information as components of their teaching materials.

Commencing July 2014, the OACU have increased its activities to encompass students. The program is a deliberate effort towards rearing students fully into the OA arena and the use of OERs for improved learning, boost creativity, engage in a wider academic circle that involves sharing with other students outside their physical geographical range, as well as educative social engagements with businesses, the public, researchers and publishers.

In developing countries, OA platforms for students are most endearing because students from such countries and regions are able to transcend the twin hurdle of financial constraints on their side and institutional constraints at accumulating sizeable and current research publications $[9,10]$. Similarly, in smaller institutions without the financial strength to amass a sizeable number of research publication, students are further restricted and under-prepared than those in big institutions.

The OA platform easily bridges these gaps. OA also offers resounding access for continued learning as a solution for the all common after school dearth in academic work, due mainly to the loss of library access after graduation. This latter challenge has often led to academic apathy on the side of most graduates. However, the knowledge of OA platform while in school is speculated to extend the studious disposition of most graduates. With the boost, scholarly publication is enjoying in developing countries [11], both students and teachers are bound to benefit from the OA platform. OACU is driving a student-centered advocacy group amongst the students to populate the ideas and explore the possibilities in OA within and beyond the university community.

\section{OA AND PBL IN COVENANT UNIVERSITY}

The platform provided by $\mathrm{OA}$ in $\mathrm{CU}$ created a ready ground for the introduction of Problem-based Learning (PBL) pedagogy at the university. PBL pedagogical system places premium demand on both the faculty and students, since learning is student-focused. The awareness provided by OA will ultimately influence the degree of positive outcomes from PBL systems. The OA platform and OERs avails both faculty and students of the myriad of teaching and learning materials for proactive engagement in PBL settings.

With faculty as facilitator, independent learning, and collaborative learning, metacognitive and critical thinking that 
will eventually lead to problem solving skills are some of the advantages that PBL offers [12]. However, one major challenge that students face in PBL system is the inability to create authentic and meaningful problems in the context of study and the content dearth the encounter. Such challenges are centered primarily on creating well-structure problems that are interesting and yet authentic as well as understanding what should constitute real problems, crafting problem statements, and such [12]. The OA platform offers students access to real problem tackled by researchers, the solutions they offered and the opening for further research, which the student can try address or attempt to address in a PBL setting.

\section{OPEN DISTANCE LEARNING - ODL}

Open and distance learning are approaches that focus on learning, teaching and training devoid of time and geographical location constraints. ODL offer learners flexible learning prospects not provided by the conventional classroom system of education [13]. The benefits offered by ODL notwithstanding, there could arose gross financial and information barriers that learners and teachers alike may face, particularly with access to current information and research results for informed teaching and learning. ODL as an organized educational system is expected to provide up-todate teaching materials, with the least constraint particularly with the issue of access.

As part of the lifelong learning program of the institution [14], the success of the ODL program relies on the ease of accessibility of learners and teachers to relevant scholarly information to attain the standards of the conventional classroom system. The ODL program leverages of the OA platform of the university and hope to draw on the resources provided by such a platform to achieve its laudable goals in Covenant University.

\section{CONCLUSION}

Establishing an operational Open Access Policy (OAP) in Covenant University has lead to far-reaching achievements in the university. The OAP platform has open up the university to improvements, which has greatly assisted in the institution drive global reckoning. Such achievements include; green OA journal set-up, launching a fund system for publications of faculty scholarly works in OA journals, providing a resource platform for the introduction of Problem-Based learning as well as constitute a major foundation for the Open and Distance Learning program of the institution. The OAP has driven improvement on other policies in the university, such the ICT and the Institutional Repository Guidelines as well as improve the general awareness level about OA among faculty, staff and students of the university.

\section{ACKNOWLEDGMENT}

The authors would like to thank the management of Covenant University for the use of data in the work.

\section{REFERENCES}

[1] A. Swan, Policy Guidelines FOR THE DEVELOPMENT AND PROMOTION OF OPEN ACCESS. Open Guidelines Series. United Nations Educational, Scientific and Cultural Organization. 2012.

[2] P. Suber, Open access policy options for funding agencies and universities. SPARC Open Access Newsletter, issue \#130, February 2, 2009.

[3] HOAP, Good practices for university open-access policies. Accessed August23, 2014. http://cyber.law.harvard.edu/hoap/Good_practices_for_universit $\mathrm{y}$ open-access policies.

[4] www.uea.ac.uk/committeeoffice/ueacombds/issc/.../dividercisc0 9d020 Accessed August 23, 2014

[5] http://www.whitehouse.gov/sites/default/files/microsites/ostp/sc holarly-pubs-\%28\%23041\%29.pdf. Accessed August 23, 2014.

[6] A.H.J. Sale, Comparison of IR content policies in Australia. First Monday,11(4), 2006.

http://www.eifl.net/faq/how-open-access-repository-

policies-are-differ. Accessed August 23, 2014.

[7] EOS, Open Access institutional repositories: A Briefing Paper. 2009.

http://www.openscholarship.org/upload/docs/application/pdf/20 09-09/open access institutional repositories.pdf

[8] RTRC, http://www.righttoresearch.org/learn/whyOA/index.shtml, Accessed 11 September, 2014.

[9] A.A. Carolina Rossini, The Open Access Movement: Opportunitoes and Challenges for Developing Countries. Let them live in interesting times. Diplo Foundation - Internet Government Program, 2007.

[10] L. Chan, Open Access and Developing Countries: The problems faced by research communities in developing countries. 2010 . http://www.openoasis.org/index.php?option=com_content\&vie $\underline{\mathrm{w}=\text { article \&catid }=78 \text { :articles } \& \mathrm{id}=28: \text { developing- }}$ countries\&Itemid $=253$.

[11] J. Bayry, Open-access boom in developing nations. Nature 497, 40 (02 May 2013). doi:10.1038/497040e.

[12] S. Hyo-Jeong K. Bosung, Learning about problem based learning: Student teachers integrating technology, pedagogy and content knowledge. Australasian Journal of Educational Technology, 25(1), 101-116. 2009.

[13] UNESCO, Open and Distance Learning: trends, policy and strategy consideration. Paris, UNESCO, 2002.

[14] E.K. Rowland Worlu, A.A.A. Atayero, S. Tuesday Owoeye, L. Olaolu Amodu, Emerging trends in lifelong learning: the covenant university perspective. Proceedings of EDULEARN14 Conference 7th-9th July 2014, Barcelona, Spain. ISBN: 978-84617-0557-3. 2014. 